\title{
The effect of conceptual change text structure on concept understanding and misconception reduction of dynamic electricity
}

\author{
Gde Parie Perdana ${ }^{1 *}$, Ketut Suma ${ }^{1}$, and Ni Made Pujani ${ }^{1}$ \\ ${ }^{1}$ Science Education Department, Post-Graduate Program, Universitas Pendidikan Ganesha, Singaraja, \\ Indonesia
}

\begin{abstract}
This study investigated the effect of conceptual change text on student understanding and misconception reduction of dynamic electricity concept. A quasi-experimental research with pre-test/post-test non-equivalent control group design was used. The subjects for this study consisted of 90 tenth-grade students. The three-tier test, the Dynamic Electricity Concept Test (DECT), was developed as pre-test and post-test to access the student conceptions. While the experimental group $(n=45)$ received a conceptual change text, the control group $(n=45)$ received an expository text. MANCOVA analysis was used to know the effect of conceptual change text structure on both dependent variables. The results of the study indicated that the student in the experimental group showed significantly higher understanding and higher misconceptions reduction compared to the students in the control group. Both groups had increased concept understanding and misconceptions reduction, however, the experimental group's result was better than the control group.

Keywords: Conceptual change text, concept understanding, misconceptions, dynamic electricity
\end{abstract}

\section{Introduction}

Students have conceptions, but not all of them are scientific concepts, there are also misconceptions. The misunderstanding that occurs will disturb the process of forming new concepts. There are various researches that have investigated misconceptions in the students in understanding science concepts. Especially in physics, the result of research found that many students have misconceptions rather than understand the concepts $[1,2]$. This shows that concept understanding is very low and the misconception level of the students is high category.

In literature, the student's personal experience, knowledge and language of science used by teachers in the classroom, and the textbooks are listed as sources of students' conceptions or reasoning [3]. Physics textbooks are generally designed in conventional text format known as expository text (ET) which contains knowledge encyclopedia. However, many studies found that expository texts cannot give cognitive conflicts to the students [4, $5,6]$ so that it is difficult to reconstruct scientific concepts in the students.

*Corresponding author : edgparie@gmail.com 
To overcome the weaknesses of the conventional text, a text or instruction can be developed using conceptual change approach that causes cognitive conflicts [7]. Therefore In the present study, it is aimed to investigate the effect of conceptual change text on student understanding and misconception reduction.

\section{Literature Review}

\subsection{Conceptual Change}

The conceptual change was proposed for the first time by Posner [7]. It is defined as a mental process in which the students can change their concept by adding new concepts to their knowledge or by changing their prior concepts into appropriate scientific concepts. Conceptual change is aimed at helping the students to understand concepts that they have not understood and to correct their misconceptions [7, 8].

Conceptual change consists of two phases, namely assimilation and accommodation [7]. The assimilation phase is the phase where the concept that the students have acquired is not sufficient to understand some new phenomena completely. The accommodation phase is the phase where the students have to change or restructure their major concepts. In addition, conceptual change also needs four stages of the process of understanding before the students can accept it, namely, (1) dissatisfaction, (2) intelligible, (3) plausible, and (4) fruitful [7].

At the understanding level, the student's haves be able to organize and interpret what they have learned, it means that they can visualize and express it in a different way using their own words each piece of information given to them [9]. Although there is a difference in the way of expressing the information in the process of understanding, the content of the information has to follow its scientific rule.

\subsection{Prior Knowledge}

The perspective of constructivists recognizes the existence of prior knowledge possessed by the student before learning in the classroom. The student is seen as a subject of learning who has possessed prior knowledge before learning [10]. The student's prior knowledge strongly supports the formation of scientific concepts in the student to achieve learning achievement [11]. It does not only support the student's learning, but it can also become an obstacle in learning since some prior knowledge is probably contradictory with the information that he/she will learn [10]. Hence, to know the student's prior knowledge becomes an important step in the teaching and learning process.

\subsection{Conceptual Change Text}

Conceptual change text (CCT) is a teaching material that is based on conceptual change approach and is designed to correct the student's misconceptions [12]. CCT can cause conceptual change and make the conceptual change that occurs in the student become permanent [3]. CCT can also be used in a remedial program [9]. A CCT is more effective than a conventional text (expository text) in restructuring the student's schemata that have undergone misconceptions [4,9]. The structure of CCT consists of 5 parts, namely (1) problem presentation, (2) common misconceptions, (3) explanation by using a scientific concept, (4) students' opinions, and (5) evaluation [13]. 


\section{Method}

This study was a quasi-experiment. The subjects were grouped based on their classes and were selected by random selection. The study used pretest-posttest non-equivalent control group design [14]. Every group was given a pretest and a posttest to measure the dependent variable before and after the treatment.

\subsection{Participants}

The subjects consisted of 90 tenth grade senior high school students. Two physics teachers volunteered to teach in this study. One teacher and the class that was taught were selected at random to become control class, and the other teacher and the class to become experiment class. The physics lesson lasted for 5 periods each week (45 minutes for each period). The researcher and the teachers held a discussion in the beginning of research about how to use CCT in the class.

\subsection{Text}

The texts were written by the researcher and reviewed by 2 lecturers (a professor and a doctor). The structure of the CCT text followed the structure developed by Ozkan and Selcuk [13]. There are five parts in the text. The first part is aimed to identify the possibility of students' misconceptions. The second part presents misconceptions and common answers that are scientifically false. The third is the scientific truth about the subject being explained. The explanation has to be very clear and can be understood. In the fourth part, when the students feel there is a difference between the misconception and the true scientific explanation, they are asked to express their own opinions. At the last part, evaluation, the aim is to know whether the students have understood the text well or not.

\subsection{Instrumentation}

The Dynamic Electricity Concept Test (DECT) was developed and used to categorize students' conceptions as understand the concept or misconception. The DECT is three-tier test includes 20 multiple-choice, reason, and student certainty of their understanding. In developing the test, 15 questions of the multiple-choice type were adopted from literature $[1,15,16,17,18,19]$ and the rest were developed by the researcher. DECT consists of 6 scopes of concepts, namely, (1) current, (2) resistance, (3) series \& parallel circuits, (4) electromotive force \& voltage difference, (5) energy \& electric power, and (6) electric measuring instrument.

Four lecturers (2 professors and 2 doctors) who teach Physics at Physics Education Department had reviewed the instrument to test its content validity. The four lecturers agreed that the test items were suitable to be used to achieve the aim and scope of the study. The testing of reliability had been done with the students who once learned the concept of dynamic electricity. The reliability of the test was 0.71 obtained by using Sperman-Brown equation.

The answer of the multiple-choice test was categorized as correct and incorrect, the students' reasons into a scientific and unscientific explanation, while the students' certainty of their answers into sure (if $>3$ ) and not sure (if $<3$ ). All student's answer categorized into 4 conceptions categories from 8 possible response types, see Table 1 . The student conception of SK category is the 
students' concept understanding. The difference score of students conception categorized $\mathrm{M}$ from pretest-posttest is misconception reduction.

Table 1. Conception Categories of Response Type [20]

\begin{tabular}{ll}
\hline Conception Categories & \multicolumn{1}{c}{ Response Types } \\
\hline Scientific knowledge (SK) & correct response + scientific explanation + sure \\
\hline Lack of knowledge (LK) & $\begin{array}{l}\text { correct response }+ \text { scientific explanation + not sure } \\
\text { incorrect response }+ \text { scientific explanation }+ \text { not sure } \\
\text { correct response }+ \text { unscientific explanation }+ \text { not sure } \\
\text { incorrect response }+ \text { unscientific explanation }+ \text { not sure }\end{array}$ \\
\hline Error (E) & incorrect response + scientific explanation + sure \\
\hline Misconception (M) & $\begin{array}{l}\text { correct response }+ \text { unscientific explanation }+ \text { sure } \\
\text { incorrect response }+ \text { unscientific explanation }+ \text { sure }\end{array}$ \\
\hline
\end{tabular}

\subsection{Data Analysis}

The data analyzed by IBM SPSS 24 software. Statistical analysis of the study was completed in four phase, (1) frequencies and mean value, (2) KolmogorovSmirnova and Shapiro-Wilk normality distribution of data analysis, (3) Levene test of homogeneity of variance, and (4) MANCOVA analysis by controlling the students' prior knowledge.

\section{Results and Discussion}

Table 2. Percentage of student's conceptions

\begin{tabular}{lllll}
\hline \multirow{2}{*}{ Concept } & \multicolumn{4}{c}{ Conception (\%) } \\
\cline { 2 - 5 } & SK & M & E & LK \\
\hline current & 36.4 & 43.2 & 5.0 & 15.4 \\
resistance & 34.2 & 43.9 & 2.0 & 19.9 \\
parallel and series circuit & 22.3 & 46.6 & 5.1 & 26.0 \\
electromotive force \& voltage difference & 19.1 & 35.3 & 0.0 & 45.6 \\
energy and electric power & 16.7 & 50.0 & 0.2 & 33.1 \\
electric measuring instrument. & 13.6 & 44.9 & 7.4 & 34.2 \\
\hline Average & 23.7 & 44.0 & 3.3 & 29.0 \\
\hline
\end{tabular}

The student's conceptions in dynamic electrical concepts are presented in Table 2. This shows that most of the students' concepts were misconceptions.

\subsection{Effect of Text Structure on Understanding and Misconception Reduction}

The MANCOVA analysis for text structure variable yielded the level of significance is below 0.05 for Pillai's Trace, Wilks' Lambda, Hotelling's Trace and Roy's Largest Root. Thus, it can be concluded that there was a difference in concept understanding and misconception reduction between the group of students who learned with CCT and the group who learned with ET.

Descriptively, the group who learned with CCT $(\bar{x}=9.8)$ had a higher average of concept understanding than ET structure group $(\bar{x}=8.7)$. Students' misconception reduction of CCT group $(\bar{x}=6.3)$ also had a higher average score than ET structure group $(\bar{x}=3.7)$. From the result, it is indicated that CCT structure is superior in improving 
concept understanding and misconception reduction. CCT is more effective than conventional text in restructuring the students' schemata that undergo misconceptions [5, 9, 13]. The effectiveness of CCT because of its advantages that gives the chance to the students to construct concepts through cognitive conflicts which occur in learning.

Table 3. Tests of Between-Subjects Effects of MANCOVA

\begin{tabular}{|c|c|c|c|c|c|c|}
\hline Source & $\begin{array}{l}\text { Dependent } \\
\text { Variable }\end{array}$ & $\begin{array}{c}\text { Sum of } \\
\text { Squares }\end{array}$ & df & $\begin{array}{l}\text { Mean } \\
\text { Square }\end{array}$ & $\mathrm{F}$ & $\mathrm{p}$ \\
\hline \multirow{2}{*}{$\begin{array}{l}\text { Corrected } \\
\text { Model }\end{array}$} & $\mathrm{CU}$ & 44.654 & 2 & 22.327 & 7.333 & .001 \\
\hline & MR & 156.898 & 2 & 78.449 & 9.387 & .000 \\
\hline \multirow[t]{2}{*}{ Intercept } & $\mathrm{CU}$ & 888.100 & 1 & 888.100 & 291.673 & .000 \\
\hline & MR & 383.346 & 1 & 383.346 & 45.868 & .000 \\
\hline \multirow{2}{*}{$\begin{array}{l}\text { Prior } \\
\text { Knowledge }\end{array}$} & $\mathrm{CU}$ & 16.876 & 1 & 16.876 & 5.542 & .021 \\
\hline & MR & 2.187 & 1 & 2.187 & .262 & .610 \\
\hline \multirow[t]{2}{*}{ Treatment } & $\mathrm{CU}$ & 29.900 & 1 & 29.900 & 9.820 & .002 \\
\hline & MR & 152.509 & 1 & 152.509 & 18.248 & .000 \\
\hline \multirow[t]{2}{*}{ Error } & $\mathrm{CU}$ & 264.902 & 87 & 3.045 & & \\
\hline & MR & 727.102 & 87 & 8.357 & & \\
\hline \multirow[t]{2}{*}{ Total } & $\mathrm{CU}$ & 7964.000 & 90 & & & \\
\hline & MR & 3134.000 & 90 & & & \\
\hline \multirow{2}{*}{$\begin{array}{l}\text { Corrected } \\
\text { Total }\end{array}$} & $\mathrm{CU}$ & 309.556 & 89 & & & \\
\hline & MR & 884.000 & 89 & & & \\
\hline
\end{tabular}

*CU $=$ Concept Understanding; MR =Misconception Reduction

Table 4. Mean difference score for concept understanding and misconception reduction

\begin{tabular}{lllrrr}
\hline \multicolumn{1}{c}{$\begin{array}{c}\text { Dependent } \\
\text { Variable }\end{array}$} & $\begin{array}{c}\text { (I) Text } \\
\text { Structure }\end{array}$ & $\begin{array}{c}\text { (J) Text } \\
\text { Structure }\end{array}$ & $\begin{array}{c}\text { Mean } \\
\text { Difference (I-J) }\end{array}$ & $\begin{array}{c}\text { Std. } \\
\text { Error }\end{array}$ & $\mathrm{p}$ \\
\hline Concept & CCT & ET & 1.154 & .368 & .002 \\
\cline { 2 - 6 } Understanding & ET & CCT & -1.154 & .368 & .002 \\
\hline $\begin{array}{l}\text { Misconception } \\
\text { Reduction }\end{array}$ & CCT & ET & 2.607 & .610 & .000 \\
\cline { 2 - 6 } & ET & CCT & -2.607 & .610 & .000 \\
\hline
\end{tabular}

\subsection{Student Concepts Understanding}

Based on the result of the testing of the hypothesis in table 4 it was apparent that there was a difference in concept understanding between the group of students who learned with the CCT structure and the group of students who learned with ET structure. The result of the hypothesis testing showed the value of $F_{\text {obs. }}=7.333(\mathrm{p}<0.05)$. Thus, it can be concluded that there was a difference in concept understanding of dynamic electricity between the students who learned with CCT structure and those who learned with ET structure.

A further testing is done by LSD method. The statistical score for the boundary of LSD rejection of the students' concept understanding is obtained 0.839 . The difference of the mean scores was $\Delta \mu_{\text {(CCT-ET) }}=1,154(\mathrm{p}<0,05)$. It shows that $\Delta \mu>$ LSD and the significance level is below 0.05 . Thus, the mean score of the group of students who learned with CCT differs significantly from that of the group of students who learned with the ET structure.

\subsection{Students' Misconception Reduction}

Based on Table 3, the result of the study showed that there was a difference in students' misconception reduction between the group of students who learned with CCT structure 
and the group of students who learned with ET structure. The result is shown with the value of $\mathrm{F}_{\text {obs. }}=9.387(\mathrm{p}<0.05)$. From a further test of the data of students' misconception reduction with $\mathrm{t}_{\text {c.v. }}=2.281$ and $\mathrm{MS} \varepsilon=8.357$ for the dependent variable of students' misconception reduction, the boundary of LSD rejection was obtained 1.390.

Based on the data in Table 4, it is apparent that the difference in the mean scores of the group who learned with CCT structure and the group who learned with ET structure was $\Delta \mu_{(\mathrm{CCT}-\mathrm{ET})}=2.607(\mathrm{p}<0.05)$. The result shows $\Delta \mu>$ LSD and the level of significance is below 0.05 . Thus, the mean score of students' misconception reduction of the CCT group of students differs significantly from that of the ET group of students.

\section{Conclusion}

Based on the results obtained in this study and the discussion, some conclusions can be drawn as follows (1) There was a difference in concept understanding and misconception reduction in the topic of Dynamic Electricity between the group of students who learned with conceptual change text (CCT) structure and the group of students who learned with conventional text structure (ET). (2) There is a difference in the students' concept understanding between the group of students who learned with CCT text structure and those who learned with ET text structure. CCT structure can improve the students' concept understanding better than ET text structure after controlling the students' prior knowledge.

(3) There was a difference in students' misconception reduction between the group of students who learned with CCT structure and those who learned with ET structure. CCT structure can increase the students' misconception reduction better than ET structure by controlling students' prior knowledge.

In the light of the findings of the study, there are several suggestions. First, the teacher has to be able to probe the students' conceptions. Second, the school has to provide books with conceptual change text structure. Thirdly, the teacher has to be able to arouse the students' interest to read so that the texts can be used optimally.

\section{References}

1. Ismail, A. Samsudin, E. Suhendi, I. Kaniawati. Prosiding Simposium Nasional Inovasi dan Pembelajaran Sains, 381 (2015).

2. K. Suma. Prosiding Seminar Nasional MIPA (2015).

3. D. K. Gürel, A. Eryilmaz. Hacettepe Üniverst. Eğitim Fakült. Dergisi, 2, 235 (2013).

4. B. J. Guzzetti. Reading \& Writing Quarterly, 16, 89 (2000).

5. M. Akpinar, M. Tan. Western Anatolia J. Edu. Sci., 139 (2011).

6. C. D. Tippett. Inter. J. Sci. Math. E., 8, 951 (2010).

7. G. J. Posner, K. A. Strike, P. W. Hewson, W. A. Gertzog. Sci. E., 66, 211 (1982).

8. N. W. Adnyani, I W. Sadia, I N. Natajaya. e-Journal Program Pascasarjana Universitas Pendidikan Ganesha, 3 (2013)

9. S. Aydin. J. Edu. Res. Behavioral Sci., 1, 1 (2012).

10. J. R. Cordova, G. M. Sinarta, S.H. Jones, G. Taasoobshirazi, D. Lombardi. Contemporary Edu. Psych., 39, 164 (2012).

11. F. Calisir, M. Eryazici, M. R. Lehto. Compt. in Human Behavior, 24, 439 (2008).

12. N. Ultay, U. G. Durukan, E. Ultay. Chem. E. Rsrch. and Pract., 16, 22 (2014).

13. G. Ozkan, G. S. Selcuk. J.of E. Res., 3, 981 (2015).

14. C. Robson, K. McCartan. Real world research, (2016).

15. S. K. Chamber, T. Andre. J. Res. Sci. Teach., 34, 107 (1995).

16. S. Sencar, A. Eryilmaz. J. Res. Sci. Teach., 41, 603 (2004). 
17. P. V Engelhardt, R. J. Beichner. Am. J. Phys., 72, 98 (2004).

18. H. Peşman, A. Eryılmaz. J. Edu. Res., 103, 208 (2010).

19. E. Taslidere. Creative Edu., 4, 273 (2013).

20. D. Kaltakçi, N. Didiş. AIP Conference Proceedings, 899, 499 (2007). 